Dr ANA STOLIĆ, viši naučni saradnik

Istorijski institut

Beograd, Republika Srbija

ana.stolic13@gmail.com

Dr RADOMIR J. POPOVIĆ, viši naučni saradnik

Istorijski institut

Beograd, Republika Srbija

rjpopovic@gmail.com

UDK: 93/94:061.61(497.1)"1947/196"

pregledni rad

primljeno: 18. jul 2018.

prihvaćeno: 21. novembar 2018.

https://doi.org/10.29362/ist20veka.2019.1.sto.193-206

\title{
INSTITUCIONALNA PRODUKCIJA ZNANJA O PROŠLOSTI: ISTORIJSKI INSTITUT U BEOGRADU OD 1947. DO KRAJA ŠEZDESETIH GODINA 20. VEKA*
}

APSTRAKT: S obzirom na to da je diskurs novog znanja ili društva znanja u značajnoj meri uticao na suštinsku promenu pozicije istorije i ostalih humanističkih nauka u savremenom svetu, u radu se analiziraju političke i društvene okolnosti, kao i okviri naučne paradigme u kojima je produkovano znanje o prošlosti u Istorijskom institutu u prve dve decenije njegovog postojanja. Nova komunistička vlast je posle 1945. godine znanje o prošlosti smatrala važnim uporištem izgradnje novog političkog, društvenog i kulturnog identiteta države. Bila je podozriva prema ,, starim kadrovima“ na Filozofskom fakultetu i u Srpskoj akademiji nauka, ali su oni ipak činili saradničko naučno jezgro prilikom osnivanja Instituta 1947. godine $i$ u prvim decenijama njegovog rada što je značajno uticalo na naučnu politiku ustanove i rezultate naučnih istraživanja.

KLJUČNE REČI: istorija, istoriografija, produkcija znanja, Jugoslavija, Istorijski institut Beograd

Pojmovi poput produkcija znanja, proizvodnja znanja, društvo znanja predstavljaju deo rečnika savremenih naučnih agendi koje su formulisane $u$ procesima velikih ekonomskih, tehnoloških, društvenih i kulturnih promena u poslednjih 30 godina. Ove promene odigrale su se najpre u vodećim postindustrijskim društvima da bi danas postale globalne. U skladu sa interesima njihovih

\footnotetext{
* Rad je deo projekata: Od univerzalnih carstava ka nacionalnim državama. Društvene i političke promene na Balkanu i Srbiji (OI177030) i Evropa i Srbi (1804-1918): Podsticaji i iskušenja evropske moderne (OI177031).
} 
nosilaca, preispitivanje i redefinisanje svrhe i ciljeva naučnih istraživanja postavljeno je kao neizbežno u uslovima promenjenih društveno-ekonomskih odnosa, ogromnog tehnološkog buma i napretka pojedinih prirodnih nauka. I ovde je, kao i u slučaju mnogih drugih fenomena, teoretičarima nauke korisno poslužilo ustanovljavanje i definisanje razlike između nekadašnjih istraživanja i naučnih rezultata odnosno, kako su formulisali, između starog znanja iz 19. i prve polovine 20. veka i novog znanja saobraženog strukturi i potrebama savremenih društava. ${ }^{1}$ Ova razlika je označena posredstvom dva modaliteta (načina organizacije znanja). Modalitet 1 karakterišu disciplinarnost, homogenost, hijerarhizovani poredak koji ima tendenciju da opstaje, autonomija naučnika i institucija, a problemi su postavljani i rešavani u kontekstu kojim su upravljali interesi specifične zajednice, najčešće akademske. Suprotno od toga, modalitetu 2 se pripisuje kontekst primene, transdisciplinarnost, heterogenost, višestruka odgovornost, privremenost, odnosno prolaznost. Evolucija i dinamika nove produkcije znanja bili su praćeni tržišnošću i komercijalizacijom znanja, omasovljenjem istraživanja i obrazovanja, konkurencijom, saradnjom i globalizacijom znanja, preoblikovanjem institucija odnosno stvaranjem novog institucionalnog pejzaža produkcije znanja i specifičnog upravljanja distribucijom naučne produkcije. Sve ovo se najpre odnosi na prirodne i tehničke nauke, dok se za društvene nauke navodi da zauzimaju poziciju ,sredine“, neku vrstu posrednika između prirodnih i humanističkih nauka. Dalje se objašnjava da je u društvenim naukama uočljiva određena distanca prema onome što izučavaju i interpretiraju, dok u većini humanističkih nauka nije zapažena takva tendencija

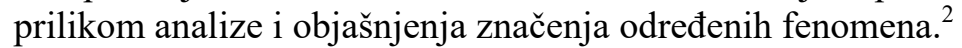

$\mathrm{Za}$ nas je svakako od posebnog interesa na koji način su određeni mesto i uloga humanističkih disciplina u strukturi novog znanja. Postoje uverenja da, iako to na prvi pogled deluje drugačije, humanističke discipline poseduju mnoge osobenosti modaliteta 2 koje ih svrstavaju u kontekst novog znanja. Argumentacija u prilog ovoj tvrdnji najčešće je zasnovana na fenomenu ogromnog rasta kulturne produkcije, koja je viđena kao produžena ruka istraživanja u humanističkim disciplinama. Prema nekim autorima, kulturna produkcija je nepravedno i pogrešno zanemarena zbog dvostrukog pogrešnog uverenja o malom učešću humanističkih nauka u procesima kreiranja bogatstva i o niskoj ceni kulturne produkcije. Nasuprot tome, ističu se brojni difuzni putevi njihovog prisustva na tržištu. Dakle, reč je o komercijalizaciji, kao važnoj odlici novog znanja. Osim toga, pominju se još transdisciplinarnost, refleksivnost i fleksibilnost kao njegove važne osobenosti a koje su, kako se ističe, prisutne i u humanističkim disciplinama. ${ }^{3}$ Reč je, naravno, pre svega o tumačenjima koja su vezana za razvijena zapadna društva.

\footnotetext{
${ }^{1}$ Michael Gibbons et al., The New Production of Knowledge, The Dynamics of Science and Research in Contemporary Societies (London: SAGE Publications, 1994), 3-4.

${ }^{2}$ Ibid., 92.

${ }^{3}$ Ibid., 90.
} 
Evropski diskurs društva znanja nastao je na osnovu široko korišćenog istoimenog koncepta društva znanja u različitim društvenim oblastima. Utemeljen Lisabonskim agendom 2000. godine, postao je strateški cilj naučnog razvoja u Evropi, u zemljama u okruženju, članicama Evropske unije, ali i deo proklamovane strategije naučnog razvoja u Srbiji. ${ }^{4}$ Promene u naučnoistraživačkoj politici u Srbiji započele su prelaskom na projekatski način finansiranja istraživanja i istraživača u naučnoistraživačkim ustanovama (2002), odnosno donošenjem Zakona o naučnoistraživačkoj delatnosti (2005). U okviru promenjene naučnoistraživačke paradigme i u Srbiji je formulisana Strategija naučnog i tehnološkog razvoja, a potom i program pod nazivom Srbija 2020. Koncept razvoja Republike Srbije do $2020 .{ }^{5}$ Strategija, zakoni i prateći akti su formalno pravno, ali donekle i suštinski ozvaničili prekid sa dotadašnjom praksom shvatanja i finansiranja naučnih istraživanja. Država je ostala (za sada) glavni finansijer nauke, ali u promenjenim uslovima u pogledu statusa istraživača, statusa naučnih ustanova, sistema vrednovanja rezultata istraživanja i sistema napredovanja. Humanističke discipline i jedan deo društvenih nauka su se našle na skliskom i nesigurnom terenu usled nametnute kvantifikacije rezultata naučnih istraživanja.

Zbog svega toga, cilj nam je da u kontekstu promenjenih okolnosti i najava daljih promena $\mathrm{u}$ radu analiziramo koncepte institucionalne produkcije naučnog znanja o prošlosti na primeru Istorijskog instituta u Beogradu u prve dve decenije njegovog postojanja (od osnivanja 1947. godine do kraja šezdesetih godina). Reč je o naučnoistraživačkoj ustanovi čija je oblast istraživanja pripadala ideološki osetljivom području proučavanja prošlosti. U periodu neposredno posle Drugog svetskog rata, novoustanovljena vlast je tragala za novim identitetom jugoslovenske države i društva. Istoriografija je trebalo da posluži kao temelj identitetskih politika. ${ }^{6}$ Posmatrano šire, ako se imaju u vidu pitanja koja su problematizovana u okviru teorija o proizvodnji identiteta, jasno je da je kontrola nad uobličavanjem znanja i svesti o prošlosti omogućavala izgradnju željene budućnosti. Ovakvim stavovima o mestu i značaju istorije kao discipline uveliko je doprinela postmodernistička kritika istoriografije koja je bila praćena velikom i burnom polemikom u vodećim centrima evropske (zapadne) istorio-

\footnotetext{
${ }^{4}$ Reč je o regionalnom istraživanju i analizi u kojima su se autori bavili pitanjima problematizacije naučnih istraživanja, istraživačkim politikama u prošlosti, odnosom između nauke i države, konceptom društva znanja (pre svega evropskim delom agende naučne paradigme), promenom paradigme u društvenom polju nauke, kao i nacionalnim istraživačkim politikama, regulatornim okvirima u Hrvatskoj, Srbiji i Sloveniji, ulaganjima u istraživanje i istraživačku produkciju u ovim zemljama. Jelena Branković, Norbert Šabić (ur.), Mihajlo Babin, Predrag Lazetić, Istraživačke politike, finansiranje i produkcija: Hrvatska, Srbija i Slovenija u uporednoj perspektivi (Beograd: Centar za obrazovne politike, 2012), 46. Dostupno na: http://www.cep.edu. rs/public/Istrazivacke_politike_-_finansiranje_i_produkcija.pdf (pristupljeno 20. 4. 2017).

${ }^{5}$ Strategija predviđa usmeravanje na nacionalne naučne prioritete, racionalizaciju mreže istraživačkih ustanova, razvijanje i zadržavanje ljudskog kapitala u nauci, jačanje naučne pismenosti društva, povezivanje nauke i industrije, osnivanje fonda za podršku inovacijama, uključivanje kapaciteta naučne dijaspore u nacionalne istraživačke aktivnosti itd. Isto, 75-76.

${ }^{6}$ Đorđe Stanković i Ljubodrag Dimić, Istoriografija pod nadzorom. Prilozi istoriji istoriografije, knj. 1 (Beograd: Službeni list SRJ, 1996), 237.
} 
grafije od devedesetih godina prošlog veka i u prvoj deceniji 21 . veka. ${ }^{7}$ Zagovornici „velikog preokreta“ $u$ istoriografiji su tvrdili da između pisanja o prošlosti i znanja o prošlosti postoji dubok jaz i da je istorijski narativ samo jedna grana lepe književnosti. Bili su skloni da svoja polazna stanovišta proglase za novu istoriju. ${ }^{8}$ Polemike su se stišale u poslednjoj deceniji zahvaljujući pomirljivim tonovima sa obe strane: oni koji su poricali i samo postojanje pojma činjenice $u$ istoriji prihvatili su da su se neki događaji zaista dogodili onako kako su ih istoričari interpretirali (ključan dokaz bio je holokaust koji se zaista dogodio); zastupnici ideje da je prošlost saznatljiva na osnovu istraživanja i interpretacije istorijskih izvora su prihvatili literarnost i narativnost kao bitne odrednice istoriografskog štiva smatrajući da i u tim okvirima postoji prostor sa saznavanje i razumevanje prošlosti. ${ }^{9}$ Može se zapaziti da se preispitivanje svrhe, cilja i rezultata bavljenja prošlošću vremenski podudarilo s pojavom diskursa novog znanja, društva znanja i to u svetskim razmerama.

U ovom radu, međutim, analiza neće biti zasnovana na paradigmi o starom i novom znanju da bi se izbeglo pojednostavljivanje i učitavanje, nego na analizi onih fenomena koji su opredelili strukturu, karakter i rezultate istraživanja u Istorijskom institutu u prve dve decenije njegovog postojanja. To su: komunistička ideologija i putevi konstruisanja novog identiteta u kome je istorija imala važnu ulogu, naučna politika, uticaj države i političkih procesa na proizvodnju ,poželjnih znanja“ o prošlosti u novoosnovanom Institutu, osobenosti znanja na osnovu naučne produkcije, izbor saradnika, upotreba znanja o prošlosti itd. Hronološki okvir je odabran zbog toga što su šezdesetih godina započeli politički i društveni procesi u jugoslovenskoj federaciji koji su se odrazili i na istorijsku nauku: slabljenje centralizovane države, jačanje nacionalnih republičkih uprava, postepeno odustajanje od ideologije bratstva-jedinstva, uvođenje samoupravljanja itd. Istorijska nauka i istoričari su postepeno oslobođeni od pritiska da moraju biti udarna pesnica vlasti u proizvodnji novog identiteta komunističke države i društva. ${ }^{10} \mathrm{U}$ isto vreme, prema nekim analizama, otpočinje proces uobličavanja novog diskursa u kome je istoriji i istoričarima namenjena uloga iznalaženja i povezivanja slike revolucionarne partijske sa srpskom nacionalnom prošlošću. ${ }^{11}$

\footnotetext{
7 Anna Green and Kathleen Troup, The Houses of History. A Critical Reader in TwentiethCentury History and Theory (Manchester: SAGE Publication 1999), 297.

${ }^{8}$ Alun Munslow, The New History (Edinburgh: Pearson Education, 2003), 5.

${ }^{9}$ Zdenka Römer Janeković, „O pisanju povijesti i znanju o prošlosti“, u: Zbornik Mirjane Gross, urednik Ivo Goldstein (Zagreb: Zavod za hrvatsku povijest Filozofskog fakulteta Sveučilišta u Zagrebu, 1999), 452-456. Dostupno na: http://www.academia. edu/7627325/O_pisanju_povijesti_i_znanju_o_pro\%C5\%A1losti_On_Historical_Writing_and_the_Knowledge_of_History (pristupljeno 30. 5. 2017).

${ }^{10}$ Đ. Stanković, Lj. Dimić, n. d., 238.

${ }^{11}$ Miroslav Timotijević, Takovski ustanak - Srpske cveti. O javnom zajedničkom sećanju i zaboravljanju u simboličnoj politici zvanične reprezentativne kulture (Beograd: Istorijski muzej Srbije, Filozofski fakultet u Beogradu, 2012) 443.
} 
Proces intenzivnijeg interesovanja i bavljenja prošlošću u Evropi započeo je tokom 19. veka u vreme konstituisanja nacionalnih država. Procvat je doživeo u prvoj polovini 20. veka, a posebno po završetku Drugog svetskog rata kada je zabeležen ogroman porast broja stručnjaka i ustanova koje su se bavile istraživanjem i interpretacijom prošlosti. Kao i u jednom broju evropskih zemalja, srpska istoriografija je prošla uobičajen put profesionalizacije bavljenja prošlošću: od odbora učenih društava, preko Akademijinih tela a potom i katedri na Velikoj školi, odnosno Univerzitetu u Beogradu. Istraživanja istorijskih izvora za srpsku srednjovekovnu istoriju započela su u Istorijskom odboru Društva srpske slovesnosti 1847. godine koje je poslalo istraživače u Veneciju, Pariz i Dubrovnik. ${ }^{12}$ U Srpskom učenom društvu, koje je 1864. godine osnovano umesto ugašenog Društva srpske slovesnosti, ustanovljen je „Odsek za nauke istorijske i državne“. Kada je 1886. godine osnovana Srpska kraljevska akademija, nauke su grupisane po stručnim akademijama. Istorijska nauka bila je u okviru Akademije društvenih nauka. Pored Akademije, značajan centar proučavanja nacionalne prošlosti krajem 19. veka postao je Filozofski fakultet Velike škole odnosno, od 1905. godine, Univerziteta u Beogradu, naročito od kada je kritički istoriografski pravac odneo prevagu nad romantičarskom strujom. Tada su univerzitetska nastava istorije i naučna istraživanja postali pokretači razvoja istorijske nauke i u Srbiji, a potpuna profesionalizacija je postignuta u Kraljevini Jugoslaviji između dva svetska rata. ${ }^{13}$

U razdoblju između dva rata pojavljuje se i ideja o ,institutima“ u smislu naučnih ustanova, ali je finansiranje predstavljalo osnovnu prepreku za njihov rad. Uz to, postavljalo se pitanje njihove svrhe pored postojanja Akademije i Univerziteta. Stanoje Stanojević je pri Srpskom seminaru na Filozofskom fakultetu u Beogradu osnovao 1923. godine Institut za prikupljanje izvora 19081918. Cilj Instituta bilo je prikupljanje građe relevantne prvenstveno za istoriju oslobodilačkih ratova Srbije. Institut je razvio široku aktivnost u prikupljanju istorijskih izvora i literature za pomenuto razdoblje. ${ }^{14}$ Balkanski institut (1934 1941) iz Beograda osnovan je u specifičnim međunarodnim okolnostima. ${ }^{15} \mathrm{U}$ Akademiji je 1935. godine inicirano osnivanje Arheološkog instituta, ali se od toga ubrzo odustalo.

Kulturnom, prosvetnom i naučnom politikom od 1945. godine rukovodila je nova komunistička vlast koja je, sa snažnim ideološkim uverenjem, rušila ili preoblikovala ustanove ,starog režima“. Međutim, u prvim poratnim godi-

${ }^{12}$ Radoslav Perović (prir.), Prvi srpski ustanak: akta i pisma na srpskom jeziku, knjiga I, 1804 1808 (Beograd: Narodna knjiga, 1977) 5-11.

${ }^{13} \mathrm{U}$ tom razdoblju pokrenuti su prvi istorijski časopisi Godišnjak Istorijskog društva u Novom Sadu 1928, a Jugoslovensko istorijsko društvo od 1935. izdaje Jugoslovenski istorijski časopis. Viktor Novak, „Jugoslovenska istoriografija između dva svetska rata i njeni savremeni zadaci“, Istorijski časopis, I, (1948), 199-203.

${ }^{14}$ Građa tog Instituta preneta je u Arhiv Istorijskog instituta 1960. godine. Stanoje Stanojević, „Skupljajte podatke za istoriju našeg ujedinjenja od 1908-1918“, Novi život, (1923), 295-296.

15 Nikola Tasić, „Balkanologija pre Balkanološkog instituta“, Spomenica povodom tridesetogodišnjice Balkanološkog instituta, Balcanica, XXX-XXXI, (2000), 7-13. 
nama nova vlast je bila veoma oprezna, podozriva i često isključiva prema vodećim predstavnicima nekadašnjeg naučnog i kulturnog života. Ona je preispitivala njihovo ponašanje tokom rata i budno motrila na njihove političke stavove prema komunističkoj ideologiji. Istovremeno je tekao proces privlačenja i diferencijacije među „starim kadrovima“ na Univerzitetu, posebno na grupama Filozofskog fakulteta. Osim Suda časti na Beogradskom univerzitetu, obrazovane su različite komisije koje su preispitivale držanje pojedinaca u Srpskoj akademiji nauka, Matici srpskoj, Srpskoj književnoj zadruzi itd. ${ }^{16}$ Pitanjima kulturne, prosvetne i naučne politike rukovodio je od 1947. godine Komitet za naučne ustanove, Univerzitet i visoke škole NR Srbije. Istorija kao disciplina i istoričari bili su posebno nadzirani, jer je Partija tragala za kadrovima koji će biti u stanju da ispišu stranice istorije Jugoslavije i da predstave novu, pobedničku istoriju Narodnooslobodilačkog rata i revolucije. Otpor prema ,buržoaskoj“ istoriografiji, koji je najčešće vodio ka raskidu s važećim principima naučnog rada, ubrzo je pokazao svoje naličje: nedostatak stručnih, obrazovanih kadrova koji bi izneli planirani posao do kraja. Težnja vlasti ka stvaranju „nove inteligencije“ koja bi bila prijemčiva za državotvorne ciljeve Komunističke partije, samo je delimično urodila plodom. ${ }^{17}$

Period učvršćivanja pozicije i uticaja nove vlasti u okviru Srpske akademije nauka (SAN) trajao je prvih nekoliko poratnih godina. Nova faza u koju je ušla ova ustanova započela je donošenjem Zakona o SAN 30. juna 1947. godine. Tim zakonom Akademija je definisana kao „najviša naučna ustanova u NR Srbiji koja okuplja najistaknutije naučnike“. Zakonom je predviđeno da Akademija u sastavu svojih odeljenja može imati ,istraživačke institute, laboratorije i kabinete, kao i biblioteke, muzeje i komisije“. Određen je delokrug i sastav šest odeljenja Akademije, od kojih je Odeljenje društvenih nauka bilo nadležno za istorijsku nauku. ${ }^{18}$ Tokom 1947. godine Srpska akademija nauka osnovala je 20 instituta.

Pripreme za osnivanje Istorijskog instituta započele su u maju 1947. godine. Ideja je bila da se oko Instituta okupe svi istoričari iz Beograda, ,kako bi se nauci dao što širi i poletniji zamah.“ Akademik Veljko Petrović, sekretar Odbora za vođenje poslova SAN, dostavio je 27. maja 1947. Komitetu za naučne ustanove, Univerzitet i visoke škole elaborat o osnivanju: Arheološkog, Geografskog, Istorijskog instituta, Instituta za proučavanje književnosti i Instituta za srpski jezik. $^{19}$ Istorijski institut osnovan je 15. jula 1947. godine. ${ }^{20}$ Komitet za naučne ustanove, Univerzitet i visoke škole je tog dana doneo i odluku kojom je akademik Viktor Novak postavljen za upravnika Istorijskog instituta, a akademik Geor-

${ }^{16}$ Đ. Stanković, Lj. Dimić, n. d., 201.

${ }^{17}$ Isto, 199.

${ }^{18}$ Dejan Medaković (ur.), Srpska akademija nauka i umetnosti, istorijat, ustrojstvo, delatnost (Beograd: Srpska akademija nauka i umetnosti, 1986), 25.

19 Arhiv Srbije (AS) u Železniku, Komitet za naučne ustanove, Univerzitet i visoke škole NR Srbije, G-89, fascikla (f.) 30 .

20 Slavenko Terzić, „Istorijski institut“, u: Enciklopedija srpske istoriografije, urednici Sima Ćirković i Rade Mihaljčić (Beograd: Knowledge, 1997), 139. 
gije Ostrogorski za njegovog zamenika. Istim rešenjem postavljeni su svi članovi i saradnici Instituta. Već na prvom sastanku Predsedništva SAN 17. jula 1947, kojim je predsedavao predsednik Akademije Aleksandar Belić, saopštena je odluka Komiteta o postavljenju upravnika i saradnika Istorijskog instituta SAN. ${ }^{21}$

Dok je Institut bio u sastavu SAN (1947-1961) upravu Instituta birala je i potvrđivala Akademija. Upravu su činili upravnik, zamenik upravnika, sekretar i Naučni savet. Do 1961. godine upravnici Instituta bili su dopisni članovi SAN Viktor Novak, Ilija Sindik i Mita Kostić. Naučni savet, koji je rukovodio naučnim radom Instituta, biralo je Odeljenje društvenih nauka SAN, nadležno za rad Instituta, na predlog upravnika Instituta iz kruga svojih članova ,i drugih priznatih stručnjaka". Prema Zakonu o organizaciji naučnog rada iz 1957. godine, prvom zakonu kojim je uređen rad naučnih ustanova na teritoriji jugoslovenske federacije, organi uprave u naučnim ustanovama bili su savet i direktor (umesto upravnika). Direktora je postavljao osnivač ustanove, a njegov izbor je potvrđivao Savet. ${ }^{22}$

Sastav saradnika Instituta u prvim godinama njegovog postojanja ukazuje na nastojanje vlasti da se za novoosnovanu naučnoistraživačku ustanovu obezbede široka osnova i podrška, ali i kontrola nad njenim radom. O tome svedoči složena mreža naučno-stručnog osoblja u koju je bio uključen veliki broj saradnika. Na osnovu nje može se, između ostalog, steći uvid u puteve i načine konstituisanja znanja, u ovom slučaju znanja o prošlosti. Tako su, osim redovnih i dopisnih članova Srpske akademije nauka (akademici Nikola Radojčić, Jovan Radonić i dopisnici Viktor Novak, Milan Budimir, Dušan Pantelić, Jorjo Tadić i Mihailo Dinić), kao stalni članovi u rad Instituta bili uključeni naučni saradnici Milan Živanović i Živan Sečanski, viši arhivista Ilija Sindik i asistent pripravnik Sava Atanacković. Treću grupu činili su honorarni saradnici, koji su svi bili u zvanju honorarnih naučnih saradnika i koji su, uglavnom, bili zaposleni u drugim ustanovama ili su bili penzioneri. Posebnu i najbrojniju grupu činili su spoljni saradnici Instituta među kojima su bili predstavnici srpskog partijskog, političkog i vojnog vrha (Mitra Mitrović, članica CK Srbije i ministarka prosvete u vladi Blagoja Neškovića, Koča Popović, general-pukovnik, Vasa Cubrilović, ministar poljoprivrede i šumarstva Narodne republike Srbije), književnici i publicisti (Jovan Popović, Vladimir Dedijer), arhivista Jugoslovenske armije Vladimir Mošin, kao i profesori, docenti i asistenti Univerziteta, kustosi muzeja, bibliotekari i advokati. ${ }^{23}$ Ako je, kako navode Stanković i Dimić, kritička istoriografija uprkos svim pritiscima nastavila da se neguje na Filozofskom fakultetu zahvaljujući profesorima iz starije predratne generacije, sasvim je izvesno da je ona bila osnova za razvoj naučnog rada i u Institutu jer su predstavnici ove škole činili većinu saradnika. ${ }^{24} \mathrm{U}$ narednim godinama pojedini saradnici su menjali kategorije a proces ustaljivanja njihovog broja i pozici-

\footnotetext{
${ }^{21}$ Godišnjak SAN, LIV, (1947), 148-149.

${ }^{22}$ Službeni list FNRJ, br. 34, 14. 8. 1957, 641-648.

${ }^{23}$ Istorijski institut 1947-2017, urednik Srđan Rudić (Beograd: Istorijski institut, 2018), 59-89.

24 Đ. Stanković, Lj. Dimić, n. d., 208.
} 
ja primetan je tek krajem prve decenije postojanja Instituta, kada se menja $\mathrm{i}$ njegov status u odnosu na Srpsku akademiju nauka.

Početni koraci Instituta u pogledu organizacije istraživačkog rada bili su veoma teški. U postojećim uslovima trebalo je uobličiti konkretnije pravce $\mathrm{i}$ ciljeve istraživanja od onih koji su pobrojani u osnivačkom aktu. Njime je bilo predviđeno da će Institut proučavati političku, privrednu i kulturnu istoriju srpskog naroda $\mathrm{i}$ da će raditi na unapređenju istorijske nauke. ${ }^{25}$ Od koncepta sveobuhvatnog proučavanja nacionalne prošlosti i istorije prostora na kojem živi ili je ranije živeo srpski narod postepeno se odustajalo, jer je 1948. godine osnovan Vizantološki institut a 1952. godine Antička sekcija je iz Instituta premeštena u Arheološki institut. Dakle, istraživanja u Institutu su posle nekoliko godina od osnivanja bila usmerena ka proučavanju nacionalne prošlosti od srednjeg do 20. veka. Rad je bio grupisan po hronološkim celinama tako da su obrazovane sekcije: Antička sekcija, Sekcija za proučavanje istorije srednjeg veka i pomoćnih istorijskih nauka, Sekcija za novi vek (kasnije podeljena na Sekciju za orijentalistiku, Sekciju za 16, 17. i 18. vek i Sekciju za 19. i 20. vek). Osim toga, odmah po osnivanju organizovana je izdavačka delatnost koja je razvrstana u dve periodične publikacije (Istorijski časopis, glasilo Instituta i Mešovita građa Miscellanea) i serije (Posebna izdanja i Zbornici).

Iz zvaničnih akata s kraja četrdesetih godina uočava se svest o širokoj naučnoj i društvenoj misiji Instituta. Tih godina nastaju Biblioteka i Arhiv Instituta. Institut je pomogao Matici srpskoj da 1949. godine osnuje istorijsku sekciju koja je svoj plan rada obrazložila i usklađivala u saradnji sa Naučnim savetom Instituta. Takođe, Institut je u Beogradu organizovao arhivistički kurs.

Istraživanja su usmeravana u skladu sa interesovanjima, metodologijom i naučnom praksom upravo onih saradnika koji su i pre rata bili zastupnici kritičkog mišljenja u istoriografiji (V. Novak, J. Tadić, I. Božić, M. Dinić, J. Radonić, G. Ostrogorski). Oni su određivali pravac istraživanja i teme. Najzastupljenije teme su bile u vezi sa srednjovekovnom prošlošću Srbije, Dubrovnika i Primorja. Ova orijentacija bila je predmet rasprava u samom Institutu između pristalica primene filozofije dijalektičkog materijalizma u istoriografiji i zastupnika kritičke istoriografije. Pitanje prioriteta u izboru tema postavio je saradnik Dušan Perović koji je smatrao da je važnije i korisnije za istoriografiju da se izučavaju i analiziraju izvori o položaju seljaka u srednjovekovnoj nemanjićkoj državi, nego da se piše o prošlosti dubrovačke slikarske umetnosti. ${ }^{26}$ Ipak, uvidom u plan rada a posebno u naučnu produkciju tokom prve decenije postojanja ustanove moguće je sagledati pravce istorijske analize i strukturu znanja o prošlosti koji su bili osobeni za Institut. Plan je zamišljen veoma ambiciozno: obimno prikupljanje osmanske i dubrovačke arhivske građe, građe za istoriju srpskog srednjeg veka, izvora za revolucionarni pokret Srba u Ugarskoj 1848/49. godine, za revolucionarni omladinski pokret u gradovima Jugoslavije, građe o odnosima Srbije i Crne Gore u 19. i 20. veku itd; kolektivni rad i saradnja na zajedničkim projektima s drugim

\footnotetext{
${ }^{25}$ Godišnjak SAN, LIV, (1947), 486-487.

${ }^{26}$ AS, Komitet za naučne ustanove, G-189, f. 31 .
} 
naučnim institutima u zemlji; pojedinačni rad na objavljivanju izvora i monografija; rad na izdavanju Istorijskog časopisa i Mešovite građe; popunjavanje fonda Biblioteke; stručno uređenje Arhiva.

$\mathrm{S}$ obzirom na loše stanje arhivske građe u Srbiji u prvim posleratnim godinama, donekle je bilo razumljivo usmerenje istraživača na pronalaženje i publikovanje istorijskih izvora iz različitih epoha i različitog porekla. Uočljivo je da je za period istorije moderne Srbije u 19. i 20. veku prednost data izvornoj građi koja se vezuje za revolucionarna zbivanja $(1804,1848)$ i narodne bune (1807). Ovo bi moglo da se tumači kao svojevrsna uvertira u procesu kreiranja diskursa kontinuiteta revolucionarne nacionalne prošlosti s revolucionarnom sadašnjošću i pobedom potlačenih masa (radnika i seljaka) u novoj socijalističkoj državi. Već pedesetih godina došlo je, kako navodi Timotijević, do decentralizacije, postepenog napuštanja jugoslovenske ideologije i uobličavanja republičkih subnacionalizama. ${ }^{27} \mathrm{Na}$ polju istorijskog istraživanja pažljivo su birani događaji i ličnosti iz nacionalne prošlosti koji su posedovali narodni revolucionarni potencijal. Ključni događaji za kreiranje kontinuiteta u revolucionarnom diskursu opštenarodnih pobuna bili su Prvi a potom i Drugi srpski ustanak 1804. i 1815. godine. Predstave o ustancima bile su „oslobođene“ dinastičkog pečata (Karađorđevića i Obrenovića) da bi postale podobne za željenu ideološku matricu. Timotijević je naveo i da je ključnu ulogu u kreiranju ove matrice imao akademik, član Instituta Vasa Čubrilović. ${ }^{28}$ Da je reč o svojevrsnim naučnim politikama koje su bile u osnovi kreiranja nove kulture kolektivnog pamćenja svedoči i osnivanje Muzeja Prvog srpskog ustanka (1954) koji je kasnije prerastao u Istorijski muzej Srbije (1963).

Ako se, međutim, analiziraju naslovi i sadržina monografskih izdanja Instituta tokom prvih 15 godina postojanja uočljiva je hronološka i tematska širina istraživačkog zamaha koji nije bio u potpunosti saobražen s krutim ideološkim zahtevima vremena. Ovo važi za nekoliko serija naučne produkcije Instituta: Posebna izdanja, Jugoslovenske zemlje u 19. veku i Jugoslovenske zemlje u 20. veku. ${ }^{29} \mathrm{Na}$ drugoj strani, jasno je da proučavanje narodnooslobodilačkog pokreta nije zaživelo u Institutu iako je neko vreme postojala sekcija za proučavanje tog perioda. Rad Instituta i odnos saradnika Instituta prema novom režimu i novoj ideologiji državna vlast je često analizirala. Tako je, na primer, u anonimnom izveštaju o Institutu s kraja 1948. godine koji je podnet Komitetu za naučne ustanove, Univerzitet i visoke škole navedeno: „U Institutu se često diskutuje o sadržini i zadacima naše istoriske nauke. Te nove zadatke na rečima usvajaju svi saradnici Instituta. Naučni kadar Instituta proučio je govore druga Tita u Beogradu i Ljubljani, u Akademijama (...). Međutim, koliko je u Institutu shvaćena suština datih direktiva u govorima druga Tita najbolje pokazuje sledeći primer. Drug Tito je našoj istoriskoj nauci postavio kao zadatak da učvršćuje i produbljuje rezultatima svog naučnog istraživanja bratstvo i jedin-

\footnotetext{
${ }^{27}$ M. Timotijević, $n$. d., 43.

${ }^{28}$ Isto, 444.

${ }^{29}$ Istorijski institut 1947-2017, 233-317.
} 
stvo naroda Jugoslavije. Ovaj zadatak se u planu naučnog rada Instituta odrazio samo formalno. Mesto da postavljeno pitanje bude predmet posebne diskusije u Institutu sa ciljem da se uoče događaji koje je buržoaska istoriografija falsifikovala (...), pa da se ta mesta naučno obrade, raskrinkaju i osvetle ciljevi koje je imala velikosrpska buržoazija, a što može biti pravi prilog Istoriskog instituta učvršćenju bratstva-jedinstva našeg naroda, Institut je mesto toga u svom planu rada (pozivajući se na savete druga Tita) postavio pozivanje predstavnika srodnih ustanova u drugim republikama radi održavanja predavanja i tome slično“ 30 Reč je, dakle, o postojanju izvesne ideološke i stručne podvojenosti između saradnika Instituta, koja je rešavana kompromisima. Tako je obezbeđen prostor za naučno-istraživački rad koji je dao dobre rezultate u prvim decenijama njegovog postojanja.

Jedna od najvažnijih promena u statusnom i organizacionom smislu za Institut u prvim decenijama njegovog postojanja nastupila je krajem pedesetih godina. Izvesno osamostaljenje Instituta u odnosu na Srpsku akademiju nauka usledilo je posle usvajanja pomenutog Zakona o organizaciji naučnog rada 1957. godine koji je počeo da se primenjuje naredne godine. Zakonom je bilo predviđeno osnivanje Saveta u naučnim ustanovama, pa su tako u Institutu pored četiri člana koje je imenovala Akademija, bila i dva koja su birali saradnici Instituta. Zakon je na velika vrata uvodio samoupravljanje kao oblik odlučivanja i težio je da odvoji akademije od naučnih ustanova, koje su ,samostalne ustanove, kojima se upravlja po načelima društvenog upravljanja“. Promene u odnosu sa Akademijom započele su donošenjem Rešenja Predsedništva SAN 10. marta 1958. kojim je Institut proglašen za naučnu ustanovu. Tim dokumentom propisani su zadaci Instituta: istraživanje i izučavanje društvene, ekonomske, političke i kulturne istorije srpskog naroda, „kao i ostalih naroda FNRJ sa kojim čine celinu", te proučavanje veza i odnosa sa narodima Balkana i Evrope; obrazovanje naučnih kadrova i briga o njihovom napredovanju; objavljivanje rezultata naučnog rada u posebnim izdanjima, zbirkama građe, zbornicima i Istorijskom časopisu; saradnja sa srodnim ustanovama u zemlji i inostranstvu. ${ }^{31}$

Zakon o Srpskoj akademiji nauka i umetnosti (SANU) iz 1960. godine predstavljao je uvod u osamostaljenje Istorijskog instituta. Zakonom je predviđeno da će Izvršno veće NR Srbije uz prethodno mišljenje Predsedništva Akademije odlučiti prema kojim će ustanovama Akademija zadržati osnivačka prava, a koji instituti će se osamostaliti. Izvršno veće je 25. marta 1961. donelo Uredbu kojom je Istorijski institut SANU postao samostalna naučna ustanova. Njegovi osnivači od tada su Izvršno veće Narodne republike Srbije, Srpska akademija nauka i umetnosti i Filozofski fakultet u Beogradu. ${ }^{32}$

Prema Uredbi Institut je 1961. godine postao samostalna ustanova sa zadatkom da „naučnim metodama proučava, istražuje i rešava sva pitanja iz oblasti istorije, a posebno da istražuje, sabira, proučava i objavljuje izvore za

\footnotetext{
${ }^{30}$ AS, Komitet za naučne ustanove, G-189, f. 29.

${ }^{31}$ Arhiva Istorijskog instituta.

${ }^{32}$ Isto.
} 
istoriju Srbije i srpskog naroda i to: izvore za istoriju starog veka, istoriju srednjeg veka, period turske vladavine, izvore za istoriju 19. i 20. veka i izvore za istorijsku geografiju; da organizuje različite oblike naučnog rada i stalnog usavršavanja i da pomaže organizovanje i izvođenje nastave trećeg stepena. ${ }^{\text {“33 }} \mathrm{Za}$ razliku od pomenutog akta Predsedništva SAN iz 1958. godine u Uredbi se ne pominju „ostali narodi FNRJ“. Naučni zadaci i ciljevi s manjim izmenama ponavljani su u statutima i drugim aktima od 1961. godine do danas.

Upravo krajem pedesetih godina došlo je do prve smene generacija $u$ Institutu. Pripadnici mlađih generacija su postepeno učvršćivali svoje pozicije. Među asistentima bili su budući profesori na Beogradskom i univerzitetima u inostranstvu. Do 1958. godine doktoriralo je 14 asistenata i saradnika. Time je znatno stabilizovana pozicija Instituta i postavljene su solidne osnove za budući samostalan rad ustanove. Kako je navela Danica Milić, direktorka Istorijskog instituta (1973-1987), ,to je bio jedan od trenutaka u kome su neki, zainteresovani za rad Instituta bili skloni da poveruju da neće biti dovoljno snage da se nastavi sve što je u prvim godinama njegovog rada započeto, pa su se čule i nepovoljne prognoze u vezi s daljom sudbinom Instituta“. Ona je istakla i da je do povećanja broja odbranjenih disertacija došlo i zbog promene zakonskih odredbi kojima su uvedeni novi uslovi za odbranu teza i određeni rokovi u kojima se one mogu odbraniti po starim pravilima. ${ }^{34} \mathrm{Na}$ drugoj strani, već tokom šezdesetih godina započeo je i proces koji će obeležiti istoriju ustanove: stalne promene u sastavu saradnika. Posle nekog vremena provedenog u Institutu, oni su odlazili na fakultete, strane univerzitete ili u druge ustanove. To je bio slučaj sa nekim članovima Instituta koji su prešli na Filozofski fakultet kao što su potonji akademici Sima Ćirković (u Institutu od 1955. do 1957), Jovanka Kalić Mijušković (1958-1962), Miloš Blagojević (1962-1972). Desetak godina (1958-1969) saradnik Instituta bio je Dimitrije Đorđević koji je potom prešao u Balkanološki institut SANU, a odatle na Univerzitet u Santa Barbari (Kalifornija).

Ovakva politika u vezi sa stručnim kadrovima uticala je na dinamiku rada, ali je takođe ponekad onemogućavala vođenje stabilne naučnoistraživačke politike. ${ }^{35} \mathrm{Na}$ odliv institutskih kadrova uticalo je verovatno i to što je Istorijski institut imao široku bazu asistenata ili već oformljenih stručnjaka za epohe od srednjeg veka do savremenog doba. U njemu su stasavali medievisti, osmanisti i istoričari koji su se bavili prošlošću moderne Srbije i Balkana. Samim tim je bilo i očekivano da Institut bude jedan od glavnih izvora stručnjaka za upražnjene fakultetske katedre. Na drugoj strani, šezdesetih i sedamdesetih godina u članstvo Instituta primljeni su i saradnici koji su u njemu proveli ceo ili veći deo radnog veka. U vezi s postepenim promenama naučne klime i stasavanjem mladih naučnih kadrova, stalnih saradnika Instituta, krajem pedesetih

\footnotetext{
${ }^{33}$ Isto.

34 Danica Milić, „Razvoj Istorijskog instituta“, u: 35 godina Istorijskog instituta 1948-1983, urednik Danica Milić (Beograd: Istorijski institut, 1984), 8-9.

${ }^{35}$ Slavenko Terzić, „Istorijski institut“, u: Enciklopedija srpske istoriografije, ur. Sima Ćirković i Rade Mihaljčić, 140-141.
} 
godina bilo je moguće da se otvori prostor za monografsko proučavanje istorije Srbije od 1903. do 1918. godine. Teme u okviru tog projekta određene su 1959. godine (Položaj radničke klase u vreme stvaranja klasnog radničkog pokreta (1900-1907), Industrijski razvitak Srbije (1900-1915), Strani kapital u rudarstvu Srbije do 1918. godine, Srpsko-italijanski diplomatski odnosi 1903-1918) i iz njihovog naziva lako se mogu prepoznati naslovi kasnije objavljenih radova istoričara Andrije Radenića, Danice Milić, Ljiljane Aleksić Pejković, Dimitrija Đorđevića, Nikole Vuča i drugih.

Analizirajući kontekst u kome je osnovan Istorijski institut 1947. godine (nova komunistička vlast, potreba za novim identitetom države i društva u čijem oblikovanju je znanje o prošlosti imalo veliku ulogu), ciljeve i zadatke njegovog rada koji su određeni nizom dokumenata, odnose sa Srpskom akademijom nauka, realizaciju planiranih istraživanja, sastav saradnika i naučnu produkciju, može se uočiti da su u postojećim uslovima bili sačuvani osnovni etički i metodološki postulati struke. Analize i interpretacije su nastajale istraživanjem izvorne građe, a ideja o objektivnosti i neutralnosti istoričara još uvek je zauzimala visoko mesto u njihovoj svesti. O tome svedoči pre svega naučna produkcija Instituta. Na drugoj strani, postoje tvrdnje da je zbog specifičnog nasleđa u srpskoj istoriografiji ipak ostao dominantan teorijsko-metodološki obrazac pozitivističkog, neorankeovskog poimanja prošlosti i nauke i tokom cele druge polovine 20 . veka. ${ }^{36}$ Iako su rad u Institutu nadzirali partijski autoriteti, oblasti istraživanja - srednji vek, osmanski period i istorija 19. veka ipak nisu bile u žiži interesovanja vlasti, koja je prvenstveno brinula o uobličavanju narativa o revolucionarnoj prošlosti Jugoslavije. Kako su naveli Stanković i Dimić mnogi istoričari su svesno birali proučavanje

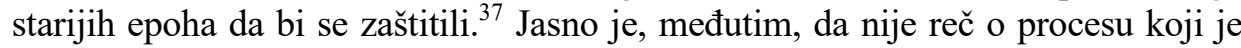
postojao paralelno s društvenom stvarnošću i vladajućom paradigmom $u$ istorijskoj nauci, već da su sukobi, kompromisi, pregovaranje i svest o značaju preživljavanja između članova Instituta doveli do takvih rezultata ili, kako je naveo Dimitrije Đorđević, oni su i pored ,,povremenih trvenja, čuvali Institut i preimućstvo koje je pružao slobodom za istraživanje i pisanje. “38

\section{REFERENCE}

- Gibbons Michael, Camille Limoges, Helga Nowotny, Simon Schwartzman, Peter Scott and Martin Trow. The New Production of Knowledge, The Dynamics of Science and Research in Contemporary Societies. London: SAGE Publications, 1994.

- Green Anna, and Kathleen Troup. The Houses of History. A Critical Reader in Twentieth-Century History and Theory. Manchester: Manchester University Press, 1999.

\footnotetext{
${ }^{36}$ Miroslav Jovanović i Radivoj Radić, Kriza istorije. Srpska istoriografija i društveni izazovi kraja 20. i početka 21. veka (Beograd: Udruženje za društvenu istoriju, 2009), 43.

${ }^{37}$ Đ. Stanković, Lj. Dimić, $n$. d., 199.

${ }^{38}$ Dimitrije Đorđević, Ožiljci i opomene, knjiga III (Beograd: Srpska književna zadruga, 2000), 56.
} 
- Đorđević, Dimitrije. Ožiljci i opomene, knjiga III. Beograd: Srpska književna zadruga, 2000.

- Istorijski institut 1947-2017. Urednik Srđan Rudić. Beograd: Istorijski institut, 2018.

- Jovanović Miroslav, i Radivoje Radić. Kriza istorije. Srpska istoriografija i društveni izazovi kraja 20. i početka 21. veka. Beograd: Udruženje za društvenu istoriju, 2009.

- Milić, Danica. „Razvoj Istorijskog instituta“. U: 35 godina Istorijskog instituta 1948-1983. Urednik Danica Milić, 113-118. Beograd: Istorijski institut, 1984.

- Medaković, Dejan (ur.). Srpska akademija nauka i umetnosti, istorijat, ustrojstvo, delatnost. Beograd: Srpska akademija nauka i umetnosti, 1986.

- Munslow, Alun. The New History. Edinburgh: Pearson Education, 2003.

- Novak, Viktor. „Jugoslovenska istoriografija između dva svetska rata i njeni savremeni zadaci“. Istorijski časopis, I, (1948), 199-217.

- Perović, Radoslav (prir). Prvi srpski ustanak: akta i pisma na srpskom jeziku, knjiga I, 1804-1808. Beograd: Narodna knjiga, 1977.

- Römer, Janeković Zdenka. „O pisanju povijesti i znanju o prošlosti“. U: Zbornik Mirjane Gross. Urednik Ivo Goldstein, 446-462. Zagreb: Zavod za hrvatsku povijest Filozofskog fakulteta Sveučilišta u Zagrebu, 1999. Dostupno na: http://www.academia.edu/7627325/O_pisanju_povijesti_i_znanju_o_pro\%C5 $\%$ Allosti_On_Historical_Writing_and_the_Knowledge_of_History (pristupljeno 30. $\overline{5} .2017)$.

- Stanković Đorđe, i Ljubodrag Dimić. Istoriografija pod nadzorom. Prilozi istoriji istoriografije, knj. 1. Beograd: Službeni list SRJ, 1996.

- Stanojević, Stanoje. „Skupljajte podatke za istoriju našeg ujedinjenja od 1908-1918“. Novi život, (Beograd, 1923), 295-296.

- Tasić, Nikola. „Balkanologija pre Balkanološkog instituta“. Spomenica povodom tridesetogodišnjice Balkanološkog instituta, Balcanica, XXX-XXXI, (2000), 7-13.

- Terzić, Slavenko. „Istorijski institut“. U: Enciklopedija srpske istoriografije. Urednici Sima Ćirković i Rade Mihaljčić, 136-141. Beograd: Knowledge, 1997.

- Timotijević, Miroslav. Takovski ustanak - Srpske cveti. O javnom zajedničkom sećanju i zaboravljanju u simboličnoj politici zvanične reprezentativne kulture. Beograd: Istorijski muzej Srbije i Filozofski fakultet, 2012.

- Šabić Norbert, Jelena Branković (ur.), Mihajlo Babin i Predrag Lazetić. Istraživačke politike, finansiranje i produkcija: Hrvatska, Srbija i Slovenija u uporednoj perspektivi, Beograd: Centar za obrazovne politike, 2012. Dostupno na: http://www.cep.edu. rs/public/Istrazivacke_politike_-_finansiranje_i_produkcija. pdf (pristupljeno 20. 4. 2017). 
ANA STOLIĆ, PhD, Senior Research Associate

Institute of History

Belgrade, Republic of Serbia

ana.stolic13@gmail.com

RADOMIR J. POPOVIĆ, PhD, Senior Research Associate

Institute of History

Belgrade, Republic of Serbia

rjpopovic@gmail.com

\title{
INSTITUTIONAL PRODUCTION OF KNOWLEDGE ABOUT THE PAST: THE INSTITUTE OF HISTORY IN BELGRADE IN THE PERIOD BETWEEN 1947 AND THE END OF THE 1960s
}

\begin{abstract}
Summary
Given the fact that the position and role of history and the other humanistic sciences in the contemporary world have been significantly affected by the discourse of a new knowledge or a new society of knowledge, this paper analyzes the political and social circumstances as well as the frameworks of the scientific paradigm within which knowledge of the past was produced in the Institute of History during the first two decades following its establishment. After 1945, the new Communist authorities considered knowledge of the past as an important factor in the building of a new political, social and cultural identity. Thus, their mistrust of the "old cadres" at the Faculty of Philosophy and the Serbian Academy of Sciences and Arts. However, it was these representatives of critical positivist historiography who constituted the scientific core of the Institute of History in the first decades of its existence. Through an analysis of the organization of the work, and the choice of associates, research topics and scientific production, it can be noticed that, despite the fact that the authorities supervised its work, the Institute managed to avoid becoming a mere instrument of the state's scientific policy in the field of historiography during this period, by including a great variety of themes covering the period from the Middle Ages to modern times. With the change of the political course in Yugoslavia and the strengthened relation to the ideology of brotherhood and unity in the 1960s, topics dealing with modern national history became more present in the Institute's projects.
\end{abstract}

KEYWORDS: history, historiography, production of knowledge, Yugoslavia, Institute of History Belgrade 